\title{
Analysis for microdeletions of $Y$ chromosome in a single spermatozoon from a man with severe oligozoospermia
}

\begin{abstract}
Since the association between Y chromosome deletions and spermatogenic failure was demonstrated in 1976, there have been many reports of Y chromosome microdeletions. Peripheral blood lymphocytes (PBLs) have been used for the analysis because the method is convenient, materials are easy to obtain, and PBL genomic DNA is similar to that of germ cells such as spermatozoa. However, PBLs originate from somatic tissue, not from germ cells. In this study, we analyzed 30 spermatozoa in semen ejaculated by an infertile male with $\mathrm{Y}$ chromosome microdeletions, while 50 spermatozoa from a normal fertile male were used as a control. The same Y chromosome microdeletion as that found in PBL was identified in each of the 12 spermatozoa which contained the Y chromosome in the infertile patient. These results indicated that spermatozoa (germ cells) had the same Y chromosome microdeletion as PBL (somatic cells). This supports the conjecture that microdeletions are transmitted to the next generation via the treatment of infertility by intracytoplasmic sperm injection.
\end{abstract}

Key words Microdeletion · Y chromosome - Oligozoosper$\mathrm{mia} \cdot$ Spermatozoa $\cdot$ Azoospermia factor $(\mathrm{AZF}) \cdot$ Deleted in azoospermia (DAZ)

S. Komori $(\triangle) \cdot$ K. Sakata $\cdot$ K. Koyoma

Department of Obstetrics and Gynecology, Hyogo College of Medicine, 1-1 Mukogawa-cho, Nishinomiya 663-8501, Japan

Tel. +81-798-45-6481; Fax +81-798-46-4163

e-mail: komor615@hyo-med.ac.jp

S. Komori · Y. Nakata $\cdot$ K. Koyoma

Laboratory of Developmental Biology and Reproduction, Institute for Advanced Medical Sciences, Hyogo College of Medicine,

Nishinomiya, Japan

H. Kato

Advanced Fertility Center, Huchu Hospital, Osaka, Japan

\section{Introduction}

Disorder of spermatogenesis is a major cause of male infertility. However, little is known about the possible contributions of genetic factors to disordered spermatogenesis (Vogt 1998). Some male infertilities may be caused by mutations that disrupt male germ cell development without affecting the soma. Although several genes related to infertility have been identified in invertebrates, such specific human genes have not yet been identified (Vogt 1998; McElreavey and Krausz 1999). Since Tiepolo and Zuffardi demonstrated $\mathrm{Y}$ chromosome microscopic deletion in azoospermic men in 1976, some critical loci have been determined in the $\mathrm{Y}$ chromosome (Tiepolo and Zuffardi 1976). Recently, the concept of the azoospermia factor (AZF) has been proposed, and three loci related to AZF (AZFa, AZFb, AZFc) have been mapped on the long arm of the Y chromosome (Vogt et al. 1996).

To date, many reports of AZF loci microdeletions have been published (Reijo et al. 1995; Qureshi et al. 1996; Stuppia et al. 1996; Foresta et al. 1997; Pryor et al. 1997; Simoni et al. 1997; van der Ven et al. 1997). For the analysis of Y chromosome microdeletions, polymerase chain reaction (PCR) has generally been performed, using DNA isolated from the peripheral blood lymphocytes (PBLs) of infertile males, because it is easy to obtain the requisite materials and isolate the DNA (Reijo et al. 1995; Qureshi et al. 1996; Stuppia et al. 1996; Pryor et al. 1997; Liow et al. 1998). Generally, the genomic DNA from PBL is considered to be the same as that in germ cells such as spermatozoa. However, PBLs originate from the mesoderm, not from the germ cells. Therefore, the results of the above studies do not directly indicate the existence of Y chromosome microdeletions in germ cells. Therefore, it is important to show that germ cells such as spermatozoa have the same microdeletions as those in PBL.

Recent advances in assisted reproductive technology (ART) have made it possible to find various remedies for infertility, especially in males. One of these techniques, the intracytoplasmic injection of a spermatozoon into the 
oocyte, can induce fertilization and pregnancy, even when the number of spermatozoa in the ejaculated semen is extremely low or spermatozoa are absent in the semen. Accordingly, this method is indicated for infertility associated with severe oligozoospermia or azoospermia, as well as the idiopathic forms of these disorders. Because genetic components, such as $\mathrm{Y}$ chromosome microdeletions, have been proposed as the pathogenetic mechanism for idiopathic severe oligozoospermia and azoospermia, the increasing use of ART has led to another problem. Namely, fertilization by intracytoplasmic sperm injection (ICSI) may result in transmission of the genetic defect that caused the spermatogenic failure to the male offspring. Several researchers have demonstrated that male offspring resulting from ICSI treatment had the same microdeletions as their fathers (De Krester 1995; Kent-First et al. 1996; Thielemans et al. 1998; Jiang et al. 1999).

In this study, we analyzed Y chromosome microdeletions in single spermatozoa and compared these deletions with the deletions identified in PBLs. We demonstrated that the $\mathrm{Y}$ chromosome microdeletions in spermatozoa were, in fact, the same as the PBL deletions. This suggests the some types of ART therapy, such as ICSI, may be responsible for the transmission of the $\mathrm{Y}$ chromosome microdeletions to succeeding generations.

\section{Subjects and methods}

\section{Patient}

An infertile Japanese man with severe oligozoospermia (sperm count, $1 \times 10^{3} / \mathrm{ml}$ ) was analyzed for Y chromosome microdeletions. The patient had the normal male karyotype $(46, \mathrm{XY})$. Serum follicle stimulating hormone (FSH) and luteinizing hormone (LH) levels were $12.7 \mathrm{IU} / 1$ and $6.5 \mathrm{IU} / \mathrm{l}$, respectively. Serum testosterone level was $349 \mathrm{ng} / \mathrm{dl}$. PCR analysis of DNA isolated from PBL indicated microdeletions in the $\mathrm{Y}$ chromosome (Kato 1998). Informed consent was obtained for the study, and ejaculated spermatozoa were collected and washed with phosphate buffered saline (PBS). Single spermatozoa were isolated with a micromanipulator (Narishige, Tokyo Japan) and placed in separate microtubes. Spermatozoa in semen ejaculated by a normal fertile male who had at least one offspring were also collected and used as control.

\section{Polymerase chain reaction}

Genomic DNA was prepared from the single spermatozoa of the patient and of the normal control, using the conventional method (Zhang et al. 1992). Random primers were commercially purchased (Operon Technologies, Alameda, CA, USA). Primers for PCR were synthesized as follows. SRY forward, GAATATTCCCGCTCTCCGGA; SRY reverse, GCTGGTGCTCCATTCTTGAG; SRY-1, GAATA TTCCCGCTCTCCGGAG; SRY-2, ACCTGTTGTCCAG
TTGCACT; sY254 forward, GGGTGTTACCAGAAGG CAAA; sY254 reverse, GAACCGTATCTACCAAAGC AGC. A single human spermatozoon was placed in an individual microtube containing $5 \mu \mathrm{l}$ of an alkaline lysis solution (200 mM KOH/50 mM dithiothreitol). After 10-min incubation at $65^{\circ} \mathrm{C}, 5 \mu \mathrm{l}$ of neutralization solution $(900 \mathrm{mM}$ Tris $\mathrm{HCl}, \mathrm{pH} 8.3 / 300 \mathrm{mM} \mathrm{KCl} / 200 \mathrm{mM} \mathrm{HCl}$ ) was added. To each lysed and neutralized sample was added $5 \mu \mathrm{l}$ of random primer ( $400 \mu \mathrm{M}$ solution), $6 \mu \mathrm{l}$ of $10 \times \mathrm{K}^{+}$free PCR buffer ( $25 \mathrm{mM} \mathrm{MgCl} /$ gelatin $1 \mathrm{mg} / \mathrm{ml} / 100 \mathrm{mM}$ Tris $\mathrm{HCl}, \mathrm{pH} 8.3$ ), $3 \mu \mathrm{l}$ of a mixture of the four dNTPs (each at $2 \mathrm{mM}$ ), and 1.87 units of Thermus aquaticus DNA polymerase (AmpliTaq Gold; Roche Molecular Systems, Branchburg, NJ, USA). Distilled deionized water was then added to bring the solution to $60 \mu \mathrm{l}$. After a preheating step at $92^{\circ} \mathrm{C}$ for $10 \mathrm{~min}$, PCR was performed, using 50 cycles of denaturing at $92^{\circ} \mathrm{C}$ for $1 \mathrm{~min}$, annealing at $37^{\circ} \mathrm{C}$ for $2 \mathrm{~min}$ and primer extension at $55^{\circ} \mathrm{C}$ for $4 \mathrm{~min}$. This was followed by a final incubation step at $55^{\circ} \mathrm{C}$ for $5 \mathrm{~min}$. A second PCR was carried out with SRY forward/reverse primers or sY254 primers, as described before (Kasumi et al. 1993). Two microliters of the first PCR solution was used for the second-round PCR. Samples in PCR buffer $\left(50 \mathrm{mM} \mathrm{KCl}, 15 \mathrm{mM} \mathrm{MgCl}_{2}, 0.01 \%\right.$ gelatin, $10 \mathrm{mM}$ Tris $\mathrm{HCl}, \mathrm{pH} 8.3$ ) were combined with dNTP $(20 \mu \mathrm{M}$ dATP, $20 \mu \mathrm{M}$ dTTP, $20 \mu \mathrm{M}$ dGTP, $20 \mu \mathrm{M}$ dCTP) mixed with $1 \mu \mathrm{M}$ oligonecleotides as primer and 1.87 units of Thermus aquaticus DNA polymerase (AmpliTaq Gold; Roche Molecular systems). After a preheating step at $95^{\circ} \mathrm{C}$ for $10 \mathrm{~min}, \mathrm{PCR}$ was carried out, using 35 cycles of denaturing at $95^{\circ} \mathrm{C}$ for $40 \mathrm{~s}$, annealing at $57^{\circ} \mathrm{C}$ for $80 \mathrm{~s}$, and primer extension at $72^{\circ} \mathrm{C}$ for $2 \mathrm{~min}$. This was followed by a final incubation step at $72^{\circ} \mathrm{C}$ for $7 \mathrm{~min}$. For the amplified SRY fragment, a third nested PCR was performed with SRY-1/2 primers. The amplified DNA was analyzed, using gel electrophoresis, performed with $2 \%$ NuSieve GTG agarose (FMC BioProducts, Rockland, ME, USA) and $1 \%$ Seakem GTG agarose (FMC BioProducts) gel in TAE buffer $(40 \mathrm{mM}$ Tris-acetate, $1 \mathrm{mM}$ ethylenediamine tetraacetic acid).

\section{Results}

The PCR amplified DNA products were analyzed by gel electrophoresis (Fig. 1). As shown in Fig. 1, 30 spermatozoa from the infertile patient were analyzed, and SRY fragment, which indicated the existence of the Y chromosome, was successfully amplified in 12 spermatozoa. Because microdeletions, including the sY254 fragment, were identified in PBLs from this patient, these 12 spermatozoa were examined for microdeletions in the sY254 regions which contained the deleted in azoospermia $(D A Z)$ gene. As shown in Fig. 1, no amplified sY254 fragments were found in any of the DNA products from the 12 spermatozoa. On the other hand, analysis of 50 spermatozoa from the normal fertile male showed amplified sY254 fragments in 13 of the 15 spermatozoa with amplified SRY fragments (Fig. 2). The results indicated that the $\mathrm{Y}$ chromosome microdeletions 
Fig. 1. Polymerase chain reaction (PCR) products from single spermatozoa in an oligozoospermic male. Arrows indicate PCR products amplified using primer set (SRY and sY254), as detailed in "subjects and methods". $M$, Size marker ( $\Phi X 174 /$ HaeIII digest). $P$, Positive control: DNA with microdeletions from peripheral blood lymphocytes (PBLs) in an oligozoospermic male. Numbers indicate samples from different spermatozoa

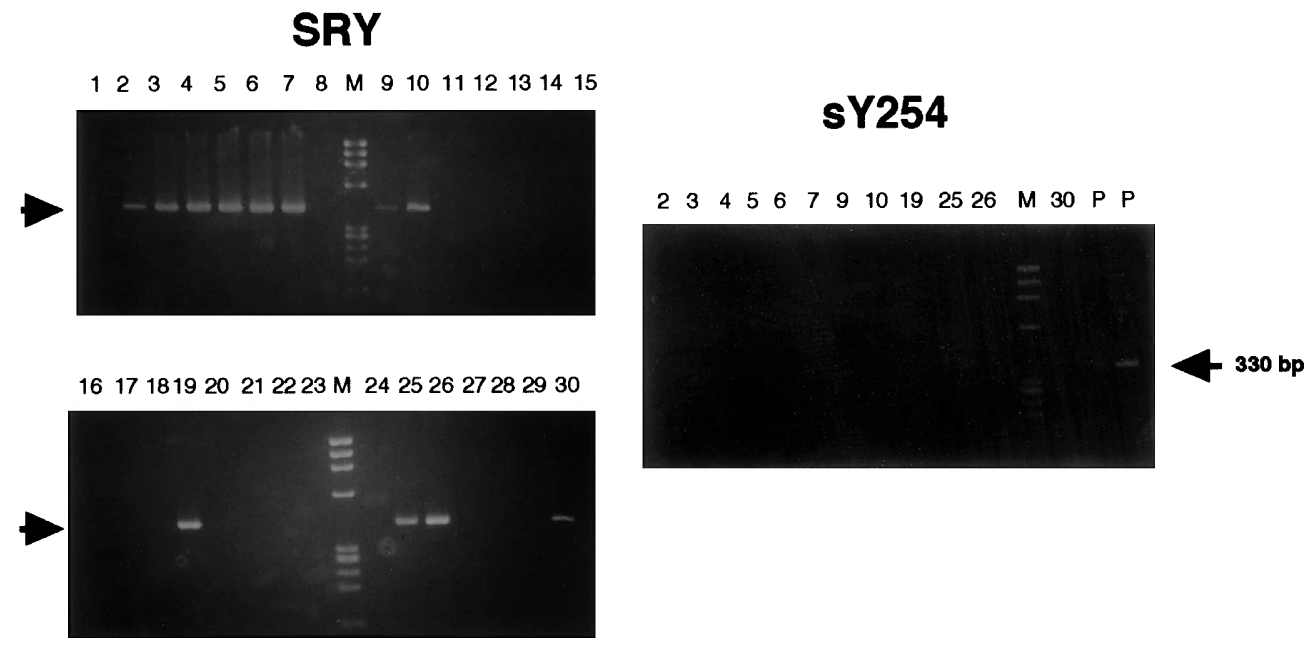

Fig. 2. PCR products from single spermatozoa in a normal fertile male. Arrows indicate PCR products amplified using primer set (SRY and sY254), as detailed in "subjects and methods". $M$, Size marker ( $\Phi X 174 / H a e I I I$ digest). $P$, Positive control: DNA with microdeletions from PBLs in an oligozoospermic male. Numbers indicate samples from different spermatozoa
SRY

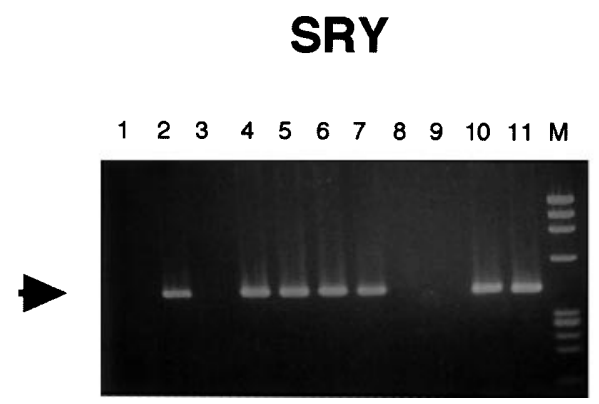

\section{sY254}

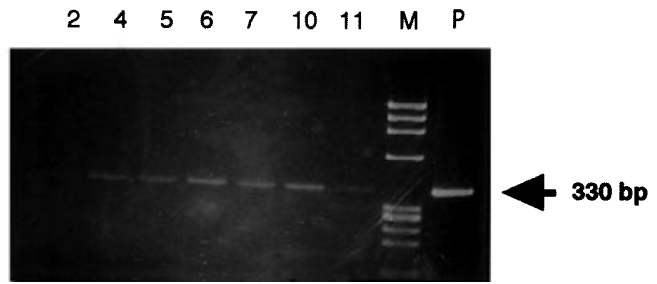

identified in spermatozoa from the infertile patient were the same as those found in the PBLs from the patient.

\section{Discussion}

In an infertile patient with severe oligozoospermia, microdeletions in the DAZ region in each spermatozoon analyzed were found to be the same as those identified in PBLs. This indicates that analysis of PBL is sufficient to detect microdeletions in spermatozoal DNA, with the exception of some special cases, such as the presence of mosaicism.

In this study, we used two-step or three-step PCR because only very small amounts of DNA could be isolated from a single spermatozoon. Therefore, it is possible that all of the DNA in a given spermatozoon was not amplified or analyzed in our study. As seen in Figs. 1 and 2, the SRY fragment was successfully amplified in only 12 of 30 spermatozoa from the infertile patient and in 15 of 50 spermatozoa from the control fertile male. These results could indicate some technical problems, such as loss of DNA. However, we used only samples that were confirmed to contain the Y chromosome, based on the existence of SRY. Interestingly, of the 15 control spermatozoa in which the SRY gene was successfully amplified, 13 showed that the sY254 fragment containing the DAZ gene was also amplified. Although the sample number was small, this finding indicated that the $\mathrm{Y}$ chromosome was present in only 13 samples, or that the PCR technique was insufficient. Although this may be a technical problem because of the extremely small amount of DNA, it also suggests that de-novo deletions may be occurring during spermatogenesis.

Before ART such as ICSI was developed, genetic factors related to male infertility were not transmitted to succeeding generations, because they critically affected spermatogenesis. Therefore, it was considered that microdeletions in the Y chromosome were a de-novo disorder that occurred during spermatogenesis. In this study, it was found that several spermatozoa from a fertile male contained the microdeletion. In light of these findings we now have to consider the possibility of transmitting a genetic disorder to the next generation whenever ART is considered as possible therapy for an infertile couple. Although there are no data available on the impact of ICSI on the transmission of genetic factors to future generations, the same microdeletions were actually identified in the offspring and infertile fathers in several other studies (De Krester 1995; Kent-First et al. 1996; Thielemans et al. 1998; Jiang et al. 1999). We have also confirmed the same microdeletions in infertile males and their sons (H. Kato, manuscript in preparation). However, little is known about the relationship between spermatogenesis disorders and microdeletions (Vogt 1998; McElreavey and Krausz 1999). Therefore we need to pursue the study of spermatogenesis as these offspring develop and mature, in order to clarify the relationship between spermatogenesis disorders and microdeletions. 


\section{References}

De Krester D (1995) The potential of intracytoplasmic sperm injection (ICSI) to transmit genetic defects causing male infertility. Reprod Fertil Develop 7:137-141

Foresta CAF, Garolla A, Rossato M, Barbaux S, de Bortoli A (1997) Y-chromosome deletions in idiopathic severe testiculopathies. J Clin Endocrinol Metab 82:1075-1080

Jiang M, Lien Y, Chen S, Ko T, Ho H, Yang Y (1999) Transmission of de novo mutations of the deleted in azoospermia genes from a severely oligozoospermic male to a son via intracytoplasmic sperm injection. Fertil Steril 71:1029-1032

Kasumi H, Komori S, Yamasaki N, Shima H, Isojima S (1993) Single nucleotide substitution of the androgen receptor gene in a case with receptor-positive androgen insensitivity syndrome. Acta Endocrinol 128:355-360

Kato H (1998) A study of microdeletions on the long arm of Y chromosome in infertile patients with oligozoospermia or azoospermia. Acta Med Hyogo 23:107-117

Kent-First MG, Kol S, Muallem A, Ofir R, Manor D, Blazer S, First N, Itskovitz-Eldor J (1996) The incidence and possible relevance of Ylinked microdeletions in babies born after intracytoplasmic sperm injection and their infertile fathers. Mol Hum Reprod 2:943-950

Liow S, Ghadessy F, Ng S, Yong E (1998) Y chromosome microdeletions, in azoospermic or near-azoospermic subjects, are located in the AZFc (DAZ) subregion. Mol Hum Reprod 4:763-768

McElreavey K, Krausz C (1999) Sex chromosome genetics'99. Am J Hum Genet 64:928-933

Pryor J, Kent-First M, Muallem A, Vna Bergen A, Nolten W, Roberts K (1997) Microdeletions in the Y chromosome of infertile men. New Engl J Med 336:534-539

Qureshi SJ, Ross AR, Ma K, Cooke HJ, McIntyre MA, Chandley AC, Hargreave TB (1996) Polymerase chain reaction screening for $Y$ chromosome microdeletion: a first step towards the diagnosis of genetically determined spermatogenic failure in men. Mol Hum Reprod 2:775-779
Reijo R, Lee T-Y, Salo P, Alagappan R, Brown LG, Rosenberg M, Rosen S, Jaffe T, Straus D, Hovatta O, de la Chapelle A, Silber S, Page DC (1995) Diverse spermatogenic defects in humans caused by $\mathrm{Y}$ chromosome deletions encompassing a novel RNA-binding protein gene. Nature Genet 10:383-393

Simoni M, Carani C, Gromoll J, Meschede D, Dworniczak B, Behre HM, Rolf C, Horst J, Abshagen K, Nieschlag E, Kamischke A (1997) Screening for deletions of the $\mathrm{Y}$ chromosome involving the $D A Z$ (deleted in azoospermia) gene in azoospermia and severe oligozoospermia. Fertil Steril 67:542-547

Stuppia L, Mastroprimiano G, Calabresse G, Peila R, Tenaglia R, Palka G (1996) Microdeletions in interval 6 of the Y chromosome detected by STS-PCR in 6 of 33 patients with idiopathic oligo- or azoospermia. Cytogenet Cell Genet 72:155-158

Thielemans B, Spiessens C, D'Hooghe T, Vanderschueren D, Legius E (1998) Genetic abnormalities and male infertility. A comprehensive review. Eur J Obstet Gynecol 81:217-225

Tiepolo L, Zuffardi O (1976) Localization of factors controlling spermatogenesis in the nonfluorescent portion of the human $\mathrm{Y}$ chromosome long arm. Hum Genet 34:119-124

van der Ven K, Montag M, Peshka B, Leygraaf J, Schwanitz G, Haidl G, Krebs D, van der Ven H (1997) Combined cytogenetic and Y chromosome microdeletion screening in males undergoing intracytoplasmic sperm injection. Mol Hum Reprod 3:699-704

Vogt P (1998) Human chromosome deletions in Yq11, AZF candidate genes and male infertility: history and update. Mol Hum Reprod 4:739-744

Vogt PH, Edelmann A, Kirsch S, Henegariu O, Hirschmann P, Kiesewetter F, Kohn FM, Schill WB, Farah S, Ramos C, Hartmann M, Hartschuh W, Meschede D, Behre HM, Castel A, Nieschlag E, Weidner W, Grone H-J, Jung A, Engel W, Haidl G (1996) Human Y chromosome azoospermia factors (AZF) mapped to different subregion in Yq11. Hum Mol Genet 5:933-943

Zhang L, Cui X, Schmitt K, Hubert R, Navidi W, Arnheim N (1992) Whole genome amplification from a single cell: implications for genetic analysis. Proc Natl Acad Sci USA 89:5847-5851 